\title{
PENGARUH PENDEKATAN FLIPPED CLASSROOM TERHADAP PEMAHAMAN KONSEP MATEMATIKA SISWA SMA
}

\author{
Made Juniantari \\ Program Studi Pendidikan Matematika, Universitas Pendidikan Ganesha \\ Email: mdjuniantari@undiksha.ac.id \\ I Gusti Ngurah Pujawan \\ Program Studi Pendidikan Matematika, Universitas Pendidikan Ganesha \\ Email: ngrpujawan@yahoo.com \\ I Dewa Ayu Gede Widhiasih \\ Program Studi Pendidikan Matematika, Universitas Pendidikan Ganesha \\ Email:mdjuniantari@undiksha.ac.id
}

\begin{abstract}
Abstrak
Penelitian ini bertujuan untuk mengetahui apakah pemahaman konsep matematika siswa yang mengikuti pembelajaran dengan pendekatan flipped classroom lebih tinggi daripada pemahaman konsep matematika siswa yang mengikuti pembelajaran konvensional. Jenis penelitian yang digunakan adalah eksperimen semu dengan desain penelitian post-test only control group. Populasi dalam penelitian ini adalah seluruh siswa kelas X MIPA SMA Negeri 4 Singaraja tahun ajaran 2017/2018. Pengambilan sampel dilakukan dengan teknik cluster random sampling untuk memperoleh 2 kelas sebagai sampel penelitian. Data dikumpulkan melalui tes pemahaman konsep matematika yang diberikan kepada siswa dalam bentuk tes uraian yang diberikan diakhir penelitian. Dari data post-test diperoleh rata-rata skor pemahaman konsep matematika siswa yang dibelajarkan dengan pendekatan flipped classroom adalah 15,265 dan rata-rata skor pemahaman konsep matematika yang mengikuti pembelajaran konvensional adalah 13,688. Dari hasil analisis data menggunakan uji-t satu ekor dengan taraf signifikansi 5\% menunjukan bahwa $t_{\text {hitung }}>t_{\text {tabel }}$. Hal ini berarti pemahaman konsep matematika siswa yang mengikuti pembelajaran dengan pendekatan flipped classroom lebih tinggi daripada pemahaman konsep matematika siswa yang mengikuti pembelajaran konvensional. Dengan kata lain pendekatan flipped classroom berpengaruh positif terhadap pemahaman konsep matematika siswa.
\end{abstract}

Kata kunci: flipped classroom, pemahaman konsep, pembelajaran konvensional

\begin{abstract}
This study aims to determine whether the understanding of mathematical concept of students who follow the learning with flipped classroom approach is higher than the understanding of mathematical concept of students who follow conventional learning. This study used quasi-experiment with post-test only control group design. The population in this study was all students of class X Mipa of SMA Negeri 4 Singaraja academic year 2017/2018. The sampling was done by cluster random sampling technique to obtain 2 classes as research sample. The data were collected through a comprehension test of mathematical concept given to students in the form of essay test at the end of the study. From the post-test, it was obtained that the average value of the understanding of mathematical concept for students who were taught by flipped classroom approach was 15.265 and the average value of understanding of mathematical concept for those who followed the conventional learning was 13,688. From the result of data analysis using t-test of one tailed with $5 \%$ significance level, it was showed that $\mathrm{t}_{\mathrm{value}}>$

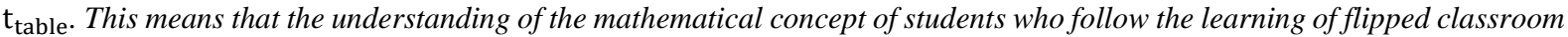
approach is higher than the understanding of mathematical concept of students who follow conventional learning. In other words, the flipped classroom approach positively influences the students' understanding of mathematical concept.
\end{abstract}

Keywords: flipped classroom, the understanding of mathematical concept, conventional learning

\section{Pendahuluan}

Matematika merupakan disiplin ilmu yang sangat dekat dan berperan penting dalam kehidupan. Matematika dapat membantu siswa untuk berpikir secara sistematis, mengembangkan kepekaan, kesadaran ataupun kepedulian siswa dalam memahami fenomena-fenomena empiris yang ditemui di kehidupan sehari-hari. Selain itu, matematika merupakan ratu ilmu pengetahuan sebab banyak ilmu-ilmu yang penemuan dan pengembangannya bergantung dari matematika. Oleh karena itu, matematika menjadi pelajaran yang diberikan kepada seluruh siswa mulai dari jenjang sekolah dasar hingga perguruan tinggi. Pembelajaran matematika di sekolah berorientasi pada tercapainya tujuan pembelajaran matematika yang telah ditetapkan dalam kurikulum 2013 yang tercantum dalam lampiran Permendikbud No.59 tahun 2014. Berdasarkan lampiran Permendikbud Nomor 59 Tahun 2014, pembelajaran matematika memiliki tujuan sebagai berikut.

1) Memahami konsep matematika, merupakan kompetensi dalam menjelaskan keterkaitan antar konsep dan menggunakan konsep maupun algoritma, secara luwes, akurat, efisien, dan tepat dalam pemecahan masalah.

2) Menggunakan pola sebagai dugaan dalam penyelesaian masalah, dan mampu membuat generalisasi berdasarkan fenomena atau data yang ada 
3) Menggunakan penalaran pada sifat, melakukan manipulasi matematika baik dalam penyederhanaan, maupun menganalisa komponen yang ada dalam pemecahan masalah dalam konteks matematika maupun di luar matematika (kehidupan nyata, ilmu, dan teknologi)

4) Mengomunikasikan gagasan, penalaran serta mampu menyusun bukti matematika dengan menggunakan kalimat lengkap, simbol, tabel, diagram, atau media lain untuk memperjelas keadaan atau masalah

5) Memiliki sifat menghargai kegunaan matematika dalam kehidupan, yaitu memiliki rasa ingin tahu perhatian, dan minat dalam mempelajari matematika, sikap ulet dan percaya diri dalam pemecahan masalah

6) Memiliki sikap dan prilaku yang sesuai dengan nilai -nilai dalam matematika dan pembelajarannya, seperti taat azas, konsisten, menjungjung tinggi kesepakatan, toleran, menghargai pendapat orang lain, santun, demokrasi, ulet, tangguh, kreatif, menghargai kesemestaan (konteks lingkungan), tanggung jawab, adil, jujur, teliti, cermat, dsb.

7) Melakukan kegiatan motorik menggunakan pengetahuan matematika

8) Menggunakan alat peraga sederhana maupun hasil teknologi untuk melakukan kegiatan-kegiatan matematik (Kemendikbud, 2014:327)

Berkaitan dengan tujuan pembelajaran matematika tersebut maka salah satu hal yang perlu diperhatikan dalam pembelajaran matematika adalah pemahaman siswa terhadap konsep matematika. Hudojo (2003) menyatakan bahwa belajar matematika perlu memahami konsep-konsep dan struktur-struktur yang terdapat dalam bahasan yang dipelajari serta mencari hubungan antara konsep dan struktur tersebut. National Council of Teacher of Mathematics (NCTM, 2000a) menyatakan bahwa pemahaman konsep merupakan komponen keahlian atau kemampuan yang penting karena konsep matematika sifatnya hierarki artinya siswa harus memahami konsep sebelumnya untuk mempermudah siswa memahami konsep selanjutnya. Ketika siswa telah memahami konsep barulah diperlukan keterampilan untuk menyelesaikan permasalahan yang kompleks menggunakan konsep tersebut. Ini berarti pemahaman konsep yang kuat dalam matematika merupakan tonggak utama dan sangat membantu siswa dalam menyelesaikan permasalahan terkait matematika.

Namun dalam kenyataannya, salah satu masalah dalam pembelajaran matematika Indonesia adalah masih rendahnya pemahaman siswa terhadap materi pelajaran matematika. Hal ini dapat dilihat dari hasil riset Trends in International Mathematics and Science Study (TIMSS) pada tahun 2015 yang dimuat dalam harian kompas yang menyatakan bahwa Indonesia berada di peringkat ke-45 dari 50 negara yang disurvei (Prahara, 2017). Rerata persentase jawaban benar siswa Indonesia dalam domain pengetahuan yang mencangkup fakta dan konsep adalah 32 sementara rerata internasional sebesar 56. Bahkan untuk soal yang sifatnya rutin siswa yang benar menjawab hanya sebesar 57\% dari seluruh siswa Indonesia yang mengikuti tes (Kemendikbud, 2015).

Hasil Ujian Nasional (UN) untuk tingkat SMA yang dikeluarkan oleh Kemendikbud juga menunjukkan hal yang serupa, dimana nilai rata-rata UN matematika untuk tingkat SMA di Indonesia mengalami penurunan sepanjang tahun 20152017. Pada tahun 2015 nilai rata-ratanya adalah 57,47 dan mengalami penurunan di tahun 2016 menjadi 47,16. Kemudian penurunan kembali terjadi ditahun 2017 dengan rata-ratanya 37,77 (Lokadata, 2017). Berdasarkan analisis yang dilakukan Alifia (2017) soal-soal UN tahun 2016 didominasi oleh soal pada aspek pengetahuan yang cenderung merupakan soal rutin yang dijawab siswa sehingga dapat menggambarkan bagaimana pemahaman konsep siswa terhadap materi yang telah dipelajari. Selain itu, Muhadjir Effendy (Maulipaksi, 2017) menyatakan bahwa secara akumulasi hasil UN akan mencerminkan keluasan dan kedalaman pemahaman siswa terhadap materi Dengan demikian hasil UN yang rendah dapat mengindikasikan bahwa pemahaman konsep matematika siswa juga rendah.

Berdasarkan analisis mengenai hasil TIMSS oleh pusat penilaian pendidikan yang dinaungi oleh Kemendikbud diketahui bahwa salah satu hal yang berpotensi berhubungan dengan pencapaian skor matematika yang lebih rendah dari kebanyakan negara lain pada tes TIMSS adalah penggunaan teknologi dalam pembelajaran matematika. Hanya $6 \%$ siswa di Indonesia yang mengguna-kan teknologi dalam pembelajaran, sedangkan secara internasional sebanyak $37 \%$ sehingga dalam pembelajaran matematika perlu memanfaatkan teknologi yang ada. Hal ini juga didukung oleh Permendikbud Nomor 22 Tahun 2016 tentang Standar Proses Pendidikan Dasar dan Menengah yang memuat 18 prinsip pembelajaran yang digunakan, salah satu prinsipnya adalah pemanfaatan teknologi dan komunikasi untuk meningkatkan efisiensi dan efektivitas pembelajaran. Oleh karena itu, pendidik diharapkan mampu memanfaatkan teknologi dan komunikasi untuk meningkatkan efektivitas dan efisiensi pembelajaran.

Pembelajaran dengan memanfaatkan teknologi memberikan dampak yang positif terhadap pemahaman konsep matematika. Hal ini diketahui dari hasil penelitian yang dilakukan oleh beberapa peneliti seperti Samsidim, dkk (2014) menyimpulkan bahwa model pembelajaran generatif berbantuan ICT berpengaruh positif terhadap pemahaman konsep matematika siswa. Penelitian yang dilakukan oleh Purwanti, dkk (2016) menyatakan bahwa terdapat pengaruh pembelajaran Discovery Learning berbantuan geogebra terhadap pemahaman konsep matematis. Begitu pula dengan penelitian yang dilakukan oleh Pratista,dkk (2017) menyatakan bahwa pemahaman konsep matematika siswa yang dibelajarkan menggunakan media pembelajaran e-learning berbasis quipper school lebih baik daripada pemahaman konsep matematika siswa yang dibelajarkan menggunakan media pembelajaran konvensional. Berdasarkan penelitian tersebut, untuk meningkatkan pemahaman konsep matematika siswa dalam pembelajaran sangat perlu untuk memanfaatkan teknologi.

Flipped classroom adalah pendekatan pembelajaran yang memanfaatkan teknologi dan memfasilitasi siswa untuk belajar tidak hanya di kelas. Pendekatan ini membalik kelas tradisional yang mana aktivitas secara tradisional terjadi di dalam kelas seperti ceramah sekarang berlangsung di luar kelas dan sebaliknya. Dengan menggunakan flipped classroom siswa memperoleh materi sebelum pembelajaran dimulai dengan menonton dan mendengarkan video atau format audio lainnya yang telah di upload terlebih dahulu oleh guru (Anonim, 2013). Video atau audio lainnya ini dapat di upload dengan bantuan media edmodo dan dapat diakses oleh siswa melalui komputer maupun gadget di rumah mereka sebelum pembelajaran di kelas. Dengan demikian, siswa yang kurang paham dengan materi dapat mengulang video sepuas mereka dan siswa dapat menghentikan video untuk mencatat poin pentingnya. Sementara waktu pertemuan di kelas dapat digunakan guru untuk memastikan pemahaman siswa (melakukan pengulangan bila diperlukan), menerapkan materi yang dipelajari di rumah, diskusi maupun debat, atau mengeksplorasi topik secara lebih mendalam dan menciptakan kegiatan belajar yang lebih kaya (Drake 
dkk, 2016). Semakin banyak waktu yang digunakan siswa untuk mengeksplorasi suatu topik maka siswa semakin paham dengan topik tersebut.

Berdasarkan penelitian yang dilakukan oleh Lomibao, dkk (2016) menyatakan bahwa menantang siswa untuk berkomunikasi secara lisan maupun tulisan di kelas matematika dapat memperdalam pemahaman konsep siswa. Langkah pembelajaran flipped classroom pun dapat menantang siswa untuk mengomunikasikan matematika secara lisan dan tulisan. Melalui langkah meringkas dan latihan soal siswa dapat mengomunikasikan matematika secara tulisan dengan menuliskan poin - poin yang diperoleh dari langkah menonton video pembelajaran. Selain mengomunikasikan secara tulisan pada langkah meringkas dan latihan soal siswa dapat mengidentifikasi contoh dan bukan contoh serta mengaplikasikan pengetahuan yang mereka peroleh dari menonton video dengan menjawab latihan soal yang ada. Di samping itu, siswa dapat mengomunikasikan matematika secara lisan melalui langkah tanya jawab dan langkah bimbingan atau latihan individu dan/atau kegiatan kelompok. Pada fase tersebut pula siswa dapat mengidentifikasi contoh dan bukan contoh dari konsep serta mengaplikasikan konsep melalui menjawab pertanyaan yang diajukan guru dan soal-soal yang diberikan. Jadi, tahap yang ada dalam pendekatan flipped classroom mampu mengakomodasi indikator pemahaman konsep matematika. Berdasarkan hal tersebut, pendekatan flipped classroom diprediksi mampu memperdalam pemahaman konsep matematika siswa.

Beberapa studi menemukan manfaat dari flipped classroom. Menurut Hamdan (dalam Drake dkk, 2016:5) setelah menggunakan pembelajaran flipped classroom selama tiga tahun di semua kelas matematika pada sekolah menengah di Minnesota, terjadi peningkatan siswa yang lulus ujian nasional matematika sebanyak 50 persen. Sementara di Colorado mengalami peningkatan nilai tes dalam matematika, sains, membaca, studi sosial, dan menulis. Menurut New York regional Information Center (dalam Drake dkk, 2016:5) setelah seorang guru menggunakan flipped classroom di sekolah di kota Niagara Falls tingkat kelulusan untuk Aljabar/Trigonometri meningkat sebesar 20 persen (siswa mencapai tingkat penguasaan meningkat 3 persen).

Berdasarkan pemaparan tersebut, diketahui bahwa pemahaman konsep matematika siswa Indonesia masih rendah dan pembelajaran dengan menggunakan pendekatan flipped classroom diduga dapat meningkatkan pemahaman konsep matematika siswa. Oleh karena itu, peneliti tertarik untuk melakukan penelitian mengenai pengaruh pendekatan flipped classroom terhadap pemahaman konsep matematika siswa kelas X Mipa di SMA Negeri 4 Singaraja. Tujuan dari penelitian ini adalah untuk mengetahui apakah pemahaman konsep matematika siswa yang mengikuti pembelajaran dengan pendekatan flipped classroom lebih tinggi dari pemahaman konsep matematika siswa yang mengikuti pembelajaran konvensional. Hasil penelitian ini diharapkan dapat bermanfaat bagi guru dan sekolah dalam menentukan alternatif pembelajaran. Dengan menginformasikan pengaruh pendekatan flipped classroom terhadap pemahaman konsep matematika siswa diharapkan dapat memberikan sumbangan pemikiran dan menambah khasanah ilmu pengetahuan di bidang pendidikan serta memperkaya bahan bacaan.

\section{Metode}

Penelitian ini merupakan penelitian quasi experiment (eksperimen semu) karena peneliti tidak dapat mengontrol semua variabel dan kondisi eksperimen secara ketat (Sugiyono, 2009). Penelitian ini dilaksanakan di SMA Negeri 4 Singaraja pada semester genap tahun ajaran 2017/2018 dengan materi trigonometri. Populasi dalam penelitian ini adalah seluruh siswa Kelas X MIPA yang berjumlah 263 siswa dan tersebar ke dalam 7 kelas.

Dalam pemilihan kelompok kontrol dan eksperimen dalam penelitian ini tidak didahului dengan uji kesetaraan, hal ini dikarenakan sampel sudah dipandang setara secara akademik sebab dalam pengelompokan siswa ke dalam kelas-kelas, siswa disebar secara merata antara siswa yang berkemampuan tinggi, sedang, dan rendah. Oleh karena itu, pada penelitian ini langsung dilakukan teknik cluster random sampling yaitu "pengambilan sampel secara tidak langsung ke unit pengamatan dengan mengambil sebuah sampel dari kelompok-kelompok unit pengamatan yang ada" (Asra, dkk, 2015:81) untuk memilih sampel penelitian. Penentuan kelompok eksperimen dan kontrol dilakukan dengan sistem pengundian yaitu kedua kelas yang muncul dalam undian langsung dijadikan sebagai sampel. Kelas dipilih sebagaimana telah terbentuk tanpa campur tangan peneliti dan tidak dilakukannya pengacakan individu. Selanjutnya dilakukan pengundian lagi terhadap kedua kelas tersebut untuk menentukan kelompok eksperimen dan kelompok kontrol. Dari hasil pengundian diperoleh kelas X Mipa 6 sebagai kelompok kontrol dan X MIPA 4 sebagai kelompok eksperimen.

Desain penelitian yang digunakan dalam penelitian ini adalah post-test only control group design yang digambarkan seperti Tabel 1 berikut.

Tabel 1. Desain Penelitian

\begin{tabular}{ccc}
\hline Kelompok & Perlakuan & Post Test \\
\hline Eksperimen & $X_{1}$ & $Y_{1}$ \\
Kontrol & $X_{2}$ & $Y_{2}$
\end{tabular}

Keterangan :

$X_{1}$ : Perlakuan dengan menerapkan pendekatan flipped classroom

$X_{2}$ : Perlakuan dengan menerapkan pembelajaran konvensional

$Y_{1}:$ Hasil post test kelompok eksperimen

$Y_{2}$ : Hasil post test kelompok kontrol

Jenis instrumen yang digunakan dalam penelitian ini berupa tes. Data yang dikumpulkan pada penelitian ini adalah pemahaman konsep matematika siswa, yang diperoleh melalui tes pemahaman konsep matematika. Tes ini diberikan pada akhir pertemuan yaitu pertemuan ke-9 pada kedua kelas sampel. Tes pemahaman konsep matematika yang digunakan berupa tes uraian/essay. Indikator pemahaman konsep matematika yang digunakan dalam penelitian ini adalah indikator yang diuraikan dalam NCTM (2000b) yaitu (1) Menyatakan ulang konsep yang telah dipelajari dengan kata-kata sendiri; (2) Mengidentifikasi yang termasuk contoh atau bukan contoh dari konsep; (3) Mengaplikasikan/menggunakan konsep dengan 
benar dalam berbagai situasi. Indikator ini yang dijadikan pedoman dalam penyusunan rubrik penskoran tes pemahaman konsep matematika siswa. Penyusunan instrumen penelitian dimulai dengan mengidentifikasi kompetensi dasar dan indikator yang akan dinilai, kemudian menyusun tes dan melakukan uji pakar oleh dua orang dosen di Jurusan Matematika yang bertujuan untuk mengetahui validitas isi dari instrumen yang dibuat. Uji validitas isi atau uji pakar ini menggunakan uji Gregory. Hasil dari uji pakar menunjukkan bahwa instrumen penelitian memiliki validitas isi sebesar 1,00 dengan kata lain seluruh butir soal dalam instrumen relevan digunakan ditinjau dari pandangan pakar.

Instrumen yang telah diuji validitas isinya kemudian diuji cobakan kepada siswa kelas XI MIPA 1 SMA Negeri 2 Singaraja yang berjumlah 32 orang. Uji coba instrumen dilakukan untuk memperoleh gambaran secara empirik bahwa tes pemahaman konsep matematika yang digunakan merupakan instrumen yang valid dan reliabel serta dapat digunakan dalam penelitian. Hasil uji coba instrumen dianalisis validitas dan reliabilitasnya. Uji validitas instrumen menggunakan koefisien korelasi product moment. Secara ringkas dapat dilihat pada Tabel 2.

Tabel 2. Rangkuman Uji Validitas Instrumen

\begin{tabular}{cccc}
\hline Butir Soal & $\boldsymbol{r}_{\boldsymbol{x y}}$ & $\boldsymbol{r}_{\text {tabel }}$ & Keterangan \\
\hline 1 & 0,353 & 0,349 & Valid \\
2 & 0,433 & 0,349 & Valid \\
3 & 0,445 & 0,349 & Valid \\
4 & $-0,206$ & 0,349 & Invalid \\
5 & 0,419 & 0,349 & Valid \\
6 & 0,534 & 0,349 & Valid \\
7 & 0,472 & 0,349 & Valid \\
8 & 0,697 & 0,349 & Valid \\
9 & 0,062 & 0,349 & Invalid \\
10 & 0,854 & 0,349 & Valid \\
11 & 0,687 & 0,349 & Valid \\
12 & $-0,004$ & 0,349 & Invalid \\
13 & 0,618 & 0,349 & Valid \\
14 & 0,774 & 0,349 & Valid \\
\hline
\end{tabular}

Selanjutnya dilakukan uji reliabilitas instrumen menggunakan rumus Alpha Cronbach. Butir soal yang diuji reliabilitas hanya butir soal yang valid sehingga hanya 11 butir soal saja yang diuji reliabilitasnya. Hasil uji reliabilitas instrumen diperoleh derajat reliabilitasnya sebesar 0,707 yang tergolong dalam kategori reliabilitas tinggi. Dari 11 soal yang valid dan reliabel dipilih 7 soal yang digunakan sebagai tes pemahaman konsep matematika siswa.

Setelah kedua kelompok sampel diberikan perlakuan dan diperoleh hasil post test dilakukan pengujian terhadap hipotesis yang diajukan. Sebelum melakukan uji hipotesis, terlebih dahulu dilakukan uji prasyarat yaitu uji normalitas menggunakan uji Lilliefors dan uji homogenitas menggunakan uji Levene. Kemudian pengujian terhadap hipotesis menggunakan uji-t satu ekor dengan taraf signifikansi 5\%. Pengujian hipotesis dilakukan untuk mengetahui apakah pemahaman konsep matematika siswa yang mengikuti pembelajaran dengan pendekatan flipped classroom lebih tinggi dari pemahaman konsep matematika siswa yang mengikuti pembelajaran konvensional. Adapun rumus uji-t yang digunakan yaitu sebagai berikut.

dengan

$$
t_{\text {hitung }}=\frac{\overline{Y_{1}}-\overline{Y_{2}}}{\sqrt{\frac{s^{2}}{n_{1}}+\frac{s^{2}}{n_{2}}}}
$$

Keterangan :

$$
s^{2}=\frac{\left(n_{1}-1\right) s_{1}^{2}+\left(n_{2}-1\right) s_{2}^{2}}{\left(n_{1}+n_{2}-2\right)}
$$

$\overline{Y_{1}}$ : rata-rata skor dari kelompok eksperimen

$\bar{Y}_{2}:$ rata-rata skor dari kelompok kontrol

$s$ : simpangan baku gabungan

$s_{1}$ : simpangan baku dari kelompok eksperimen

$s_{2}$ : simpangan baku dari kelompok kontrol

$n_{1}$ : banyak subjek dari kelompok eksperimen

$n_{2}$ : banyak subjek dari kelompok kontrol

\section{Hasil dan Pembahasan}

Data skor pemahaman konsep matematika siswa yang diperoleh dari post-test yang diberikan kepada kedua kelas sampel dapat dilihat pada Tabel 3.

Tabel 3. Rangkuman Analisis Data Skor Pemahaman Konsep Matematika Siswa 


\begin{tabular}{lccc}
\hline & & \multicolumn{2}{c}{ Kelompok Sampel } \\
\cline { 3 - 4 } No. & Variabel & Eksperimen & Kontrol \\
\hline 1. & Banyak Siswa & 34 & 32 \\
2. & Rata-rata & 15,265 & 13,688 \\
3. & Varians & 1,831 & 1,674 \\
\hline
\end{tabular}

Dari Tabel 3, dapat dilihat bahwa rata-rata skor pemahaman konsep matematika antara siswa yang dibelajarkan menggunakan pendekatan flipped classroom lebih tinggi dari rata-rata skor pemahaman konsep matematika siswa yang dibelajarkan dengan pembelajaran konvensional.

Sebelum dilakukan uji hipotesis, terlebih dahulu dilakukan uji prasyarat yaitu uji normalitas dan uji homogenitas terhadap hasil tes pemahaman konsep matematika siswa. Hasil uji normalitas sebaran data pemahaman konsep matematika siswa kelompok eksperimen dan kontrol menggunakan uji Lilliefors dapat dilihat pada Tabel 4.

Tabel 4. Rangkuman Hasil Uji Normalitas Data Pemahaman Konsep Matematika Siswa

\begin{tabular}{ccc}
\hline Kelompok & Lhitung & Ltabel \\
\hline Eksperimen & 0,127 & 0,152 \\
Kontrol & 0,145 & 0,157
\end{tabular}

Berdasarkan Tabel 4 diatas, terlihat bahwa $L_{\text {hitung }}$ kedua kelompok sampel yaitu eksperimen dan kontrol kurang dari $L_{\text {tabel }}$ kelompok bersangkutan. Dengan demikian $\mathrm{H}_{0}$ diterima dan disimpulkan bahwa data pemahaman konsep matematika siswa kelompok eksperimen dan kontrol berdistribusi normal. Adapun rangkuman hasil uji homogenitas varians dari data pemahaman konsep matematika siswa untuk kedua sampel dengan uji levene dapat dilihat pada Tabel 5.

Tabel 5. Rangkuman Hasil Uji Homogenitas Data Pemahaman Konsep Matematika Siswa

\begin{tabular}{cc} 
Variabel & Nilai \\
\hline$(\boldsymbol{N}-\boldsymbol{k}) \sum_{i=1}^{\boldsymbol{k}}\left(\overline{\boldsymbol{d}_{\boldsymbol{\imath}}}-\overline{\boldsymbol{d}}\right)^{2}$ & 16,425 \\
$(\boldsymbol{k}-\mathbf{1}) \sum_{i=1}^{\boldsymbol{k}} \sum_{j=1}^{\boldsymbol{n}}\left(\boldsymbol{d}_{\boldsymbol{i} j}-\overline{\boldsymbol{d}_{\boldsymbol{\imath}}}\right)^{2}$ & 68,563 \\
$W$ & 0,240 \\
$F_{\text {tabel }}$ & 3,99
\end{tabular}

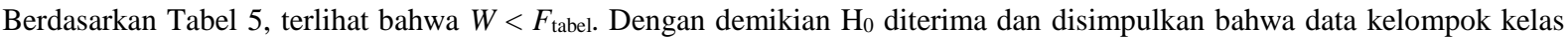
eksperimen dan kontrol memiliki varians yang homogen. Dari hasil uji normalitas dan uji homogenitas yang telah dilakukan memperlihatkan bahwa data dari kelompok eksperimen dan kontrol berdistribusi normal dan homogen. sehingga, pengujian hipotesis bisa dilakukan dengan menggunakan uji-t satu ekor kanan. Tabel 6. Rangkuman Hasil Analisis Uji- $t$

\begin{tabular}{ccccc}
\hline Kelompok & $N$ & $\bar{Y}$ & $s_{\text {gab }}^{2}$ & $t_{\text {hit }}$ \\
\hline Eksperimen & 34 & 15,265 & 3,086 & 3,645 \\
Kontrol & 32 & 13,688 & \\
\hline
\end{tabular}

Berdasarkan perhitungan didapat $t_{\text {hitung }}=3,645$. Adapun nilai $t_{\text {tabel }}$ pada taraf signifikasi 0,05 dengan dk $=74$ adalah 1,669. Apabila dibandingkan, nilai thitung $>t_{\text {tabel }}$. Dengan demikian $\mathrm{H}_{0}$ ditolak. Hal ini berarti pemahaman konsep matematika siswa yang mengikuti pembelajaran dengan pendekatan flipped classroom lebih tinggi daripada pemahaman konsep matematika siswa yang mengikuti pembelajaran konvensional. Dengan kata lain, pendekatan flipped classroom berpengaruh positif terhadap pemahaman konsep matematika siswa. Temuan ini sejalan dengan hasil penelitian yang dilakukan oleh Turan dan Yuksel (2016) yang menyatakan bahwa siswa yang dibelajarkan dengan flipped classroom memiliki prestasi belajar yang lebih tinggi dan beban kognitif yang lebih rendah daripada siswa yang dibelajarkan dengan pembelajaran tradisional. Hasil penelitian yang serupa juga diperoleh oleh sun dan $\mathrm{Wu}$ (2016) bahwa siswa yang dibelajarkan dengan flipped classroom memiliki prestasi belajar yang lebih tinggi daripada siswa yang dibelajarkan dengan pembelajaran konvensional. Salah satu kemampuan terpenting dalam belajar matematika yang berpengaruh pada prestasi belajar siswa adalah pemahaman konsep sehingga prestasi belajar yang tinggi dapat memberikan gambaran bahwa pemahaman konsep siswa juga tinggi.

Pemahaman konsep matematika siswa pada kelompok eksperimen lebih tingginya daripada kelompok kontrol dikarenakan dalam pelaksanaan proses pembelajaran siswa lebih banyak memiliki kesempatan untuk mengungkapkan kembali konsep yang telah dipelajari dengan kata-kata sendiri, mengidentifikasi yang termasuk contoh dari konsep dan menerapkannya untuk menyelesaikan suatu permasalahan melalui langkah pembelajaran dengan pendekatan flipped classroom. Dengan pendekatan ini proses pembelajaran tidak hanya terpaku di kelas saja, siswa memperoleh materi pembelajaran dan latihan soal di luar sekolah dan memfokuskan kegiatan di kelas untuk berdiskusi dan membahas hal-hal yang kurang mereka pahami. Pendekatan ini membuat siswa memiliki waktu belajar yang lebih banyak dan siswa dapat menyesuaikan waktu belajar serta kecepatan belajarnya. Hal ini membuat proses belajar mengajar di kelas menjadi lebih efektif karena siswa menjadi lebih aktif dalam pembelajaran sehingga berdampak pada pemahaman konsep siswa. Hal ini sejalan dengan penelitian yang dilakukan Choirudin (2017) yang menyatakan bahwa keaktifan siswa berpengaruh positif terhadap hasil belajar matematika siswa. Dalam proses untuk mendapatkan hasil belajar yang baik, siswa perlu memahami konsep atau materi pembelajaran dengan baik sehingga keaktifan siswa dalam pembelajaran matematika dapat mempengaruhi pemahaman konsep siswa. 
Pendekatan flipped classroom merupakan pendekatan pembelajaran yang membagi dua jenis pembelajaran yaitu pra pembelajaran dan pembelajaran di kelas. Pada saat pra pembelajaran atau sebelum pembelajaran di kelas siswa telah memperoleh pemaparan materi melalui video pembelajaran yang diunggah oleh guru di edmodo 1-3 hari sebelum pembelajaran di kelas. Hal ini menuntut siswa untuk belajar secara mandiri dan memaknai sendiri materi pembelajaran yang akan dibahas di kelas sehingga siswa lebih memahami materi dan telah memiliki bekal pengetahuan sebelum proses pembelajaran di kelas yang membuat proses diskusi di kelas menjadi sangat efektif. Hal ini sejalan dengan penelitian dari Mahayukti, dkk (2015) menyatakan bahwa terdapat kontribusi signifikan kemandirian belajar terhadap pemahaman konsep aljabar serta penelitian dari Yeni Merlin (2014) yang menyatakan bahwa mahasiswa memiliki persepsi positif dengan penambahan materi melalui video dan latihan-latihan, dengan adanya pembelajaran flipped classroom sebagian besar mahasiswa merasa lebih memahami materi dan menilai bahwa video yang dibagikan telah membantu pemahaman mereka atas materi yang dibelajarkan. Selain itu, siswa yang tidak hadir di kelas pun tidak ketinggalan materi pembelajaran karena mereka bisa memperoleh materi dengan menonton video pembelajaran yang telah di upload. Setelah menonton video pembelajaran, siswa diminta untuk meringkas dan menerapkan pemahaman mereka dengan mengerjakan latihan soal sesuai dengan kemampuannya.

Pada langkah meringkas ini siswa memiliki kesempatan untuk mengungkapkan kembali segala informasi tentang materi yang mereka peroleh dari video dalam bahasa mereka sendiri. Penggunaan bahasa sendiri mampu meningkatkan pemahaman siswa terhadap materi yang diringkas dan siswa dapat mengingat poin penting dalam materi tersebut. Hal ini sesuai dengan penelitian yang dilakukan oleh Lomibao, dkk (2016) menyatakan bahwa menantang siswa untuk berkomunikasi secara lisan maupun tulisan di kelas matematika dapat memperdalam pemahaman konsep siswa. Selain meringkas, siswa dapat menerapkan konsep yang telah mereka pelajari dengan mengerjakan soal latihan yang di upload oleh guru bersamaan dengan video pembelajaran. Melalui latihan soal ini siswa sendiri akan mengetahui sejauh mana pemahaman mereka terhadap materi yang telah dipelajari melalui video. Tujuan langkah ini adalah agar guru dapat mengetahui bagaimana pemahaman siswa dan cara mereka mengaplikasikan pengetahuannya sehingga guru dapat merencanakan pembelajaran di kelas agar sesuai dengan kondisi siswa. Apabila siswa mengalami kesulitan dalam mengerjakan soal atau ada hal yang kurang mereka pahami, siswa dapat berdiskusi dengan siswa lainnya atau menghubungi guru melalui fitur messages atau pesan pada edmodo. Ketika siswa telah selesai mengerjakan latihan soal, siswa diminta untuk memfoto pekerjaan mereka dan mengunggahnya di latihan soal dengan mengklik submission sehingga pekerjaan mereka akan tersimpan di edmodo dan dapat dikomentari oleh guru bila diperlukan.

Langkah selanjutnya adalah kegiatan pembelajaran di kelas yaitu tanya jawab isi video. Pada langkah ini guru meminta siswa untuk mengungkapkan kembali konsep yang mereka peroleh dari langkah menonton video pembelajaran secara lisan serta memberikan beberapa pertanyaan untuk mengetahui pemahaman mereka terhadap materi dan mencegah terjadinya miskonsepsi. Selain itu, guru juga memberikan kesempatan kepada siswa untuk menanyakan hal-hal yang kurang mereka pahami terkait materi yang terdapat pada video dan memberikan kesempatan kepada siswa lain untuk menanggapi pertanyaan temannya, bila tanggapan siswa dirasa kurang lengkap atau siswa tidak ada yang memberikan tanggapan maka guru memberikan penjelasan tambahan. Kemudian dilanjutkan dengan membahas latihan soal yang telah dikerjakan siswa dengan memberikan kesempatan kepada siswa untuk mempresentasikan jawabannya dan meminta siswa lainnya untuk menanggapi pekerjaan temannya. Dalam hal ini guru akan menjadi penengah bila ada perbedaan pendapat dan juga memberikan penguatan. Karena sebelum pembelajaran di kelas siswa telah mempersiapkan diri dengan menonton video pembelajaran dan mengerjakan latihan soal dengan baik, muncul rasa percaya diri siswa untuk mengungkapkan pendapatnya dan mempresentasikan jawaban mereka sehingga pada langkah ini siswa sangat antusias bahkan berebut agar bisa ditunjuk oleh guru. Hal ini sejalan dengan penelitian yang dilakukan Jacob Enfield (2013) bahwa pembelajaran flipped classroom membuat siswa menjadi lebih percaya diri terhadap kegiatan di kelas dan siap menerima kegiatan pembelajaran dengan motivasi yang lebih baik dari pembelajaran biasa. Hasil yang serupa juga dinyatakan oleh Uzunboylu dan Damla (2015) bahwa lingkungan flipped classroom membuat siswa menjadi lebih aktif dibandingkan dengan lingkungan pembelajaran tradisional.

Setelah melalui langkah tanya jawab isi video, langkah selanjutnya yaitu bimbingan atau latihan individu dan/atau kegiatan kelompok. Pada langkah ini guru memberikan siswa soal-soal yang tingkatannya lebih sulit dari soal-soal pada latihan soal untuk lebih memperdalam pemahaman siswa dan mengasah kemampuan mereka dalam mengaplikasikan konsep yang telah dipelajari. Dalam hal ini guru bisa memilih apakah akan dilakukan latihan individu atau kegiatan kelompok, pemilihan ini berdasarkan kondisi yang dirasakan guru setelah melalui langkah sebelumnya khususnya tanya jawab isi video. Bila hampir seluruh siswa memahami materi dan mampu mengerjakan latihan soal dengan baik maka guru dapat memilih latihan individu, tetapi bila masih banyak siswa yang belum mampu mengerjakan latihan soal dengan benar maka guru memilih kegiatan kelompok dengan membentuk kelompok yang heterogen agar siswa yang sudah memahami dengan baik bisa membantu atau mengajarkan siswa lainnya. Ketika siswa melakukan diskusi guru berkeliling dan memberikan bimbingan serta arahan yang diperlukan siswa agar mereka mampu mengerjakan tugas yang diberikan. Kegiatan akhir dari langkah ini yaitu guru meminta siswa untuk mempresentasikan hasil diskusinya dan siswa lain menanggapinya.

Pada akhir pembelajaran guru mengevaluasi selama proses pembelajaran berlangsung dan memberikan tanda turus pada absen siswa yang merupakan tanda keaktifan bagi siswa yang telah membuat tugas yang diberikan serta berani untuk mengungkapkan pendapat dan mempresentasikan pekerjaannya. Hal ini dimaksudkan agar siswa lebih giat belajar dan meningkatkan motivasi belajar agar lebih baik dari sebelumnya.

Dalam pembelajaran dengan pendekatan flipped classroom, guru berperan sebagai fasilitator mulai dari menyediakan suatu platform sebagai wadah siswa untuk belajar dan berdiskusi di luar kelas, sampai video pembelajaran yang ditonton oleh siswa. Siswa lebih mandiri dalam belajar serta dapat menyesuaikan dengan waktu dan kecepatan belajar mereka namun tetap dalam bimbingan dari guru. Sedangkan pada pembelajaran konvensional, pada tahap awal guru menyajikan materi sembari meminta siswa untuk mencermati materi tersebut pada modul yang dibawa siswa serta memberikan kesempatan kepada siswa untuk bertanya bila ada yang kurang dipahami. Hal ini membuat siswa kurang mampu untuk belajar secara mandiri dan memaknai sendiri materi pembelajaran. Selain itu, pada saat diskusi kelompok siswa kurang percaya diri dengan pemikiran dan jawabannya karena siswa belum memahami konsep dari materi yang mereka peroleh dengan baik dan benar sehingga mereka sering bertanya kepada guru dan sangat membutuhkan arahan dan bimbingan dari guru. Selain itu, siswa yang bersedia 
mempresentasikan hasil diskusi kelompoknya pun dominan merupakan siswa yang memiliki kemampuan yang lebih tinggi. Di samping itu, guru tidak dapat memberikan bimbingan dan arahan ketika siswa kesulitan mengerjakan pekerjaan rumah yang diberikan sehingga siswa harus menunggu mendapat penjelasan hingga pertemuan selanjutnya.

Secara umum, pelaksanaan pendekatan flipped classroom dapat berjalan dengan baik. Walaupun demikian, dalam pelaksanaannya tidak luput dari adanya kendala-kendala. Adapun kendala-kendala yang dihadapi adalah pada minggu awal penelitian ada beberapa siswa yang lupa akan password untuk login ke edmodo sehingga mereka tidak dapat menonton video dan mengerjakan tugas yang diberikan, kemudian untuk mengatasi hal tersebut dengan meminta siswa untuk men-download aplikasi edmodo di gadget mereka sehingga mereka hanya cukup login sekali saja. Pada saat pertemuan awal masih banyak siswa yang tidak mengakses edmodo dan mengerjakan tugas yang diberikan serta siswa masih terlihat malu dan takut untuk mengungkapkan pendapat dan mempresentasikan jawabannya sehingga pembelajaran di kelas menjadi kurang efektif. Hal ini karena siswa masih belum terbiasa dengan pembelajaran flipped classroom dan kurang ada persiapan sebelum pembelajaran sehingga mereka kurang memiliki rasa percaya diri. Untuk mengatasi hal tersebut guru selalu memberikan penghargaan bagi siswa yang sudah mengerjakan tugas di edmodo dan mau mengungkapkan pendapat atau mempresentasikan jawaban dengan memberikan turus sebagai tanda keaktifan siswa. Cara ini sangat efektif karena berangsur-angsur siswa mulai berani mengajukan pendapat dan mempresentasikan jawabannya dan ketika sebagian besar siswa bisa menjawab soal latihan di edmodo , mereka akan berebut agar bisa ditunjuk oleh guru. Melihat siswa yang berebut guru memberikan kesempatan kepada siswa yang tanda turusnya paling sedikit untuk mengungkapkan pendapat atau pekerjaannya, sementara siswa lain diminta untuk menanggapi.

Meskipun memiliki kendala dalam penerapannya, namun kendala tersebut telah ditangani dengan baik, serta berdasarkan hasil pengujian hipotesis dan gambaran deskriptif yang diuraikan, pendekatan flipped classroom membawa dampak positif terhadap pemahaman konsep matematika siswa. Hal ini dibuktikan dengan hasil post test yang menunjukkan bahwa pemahaman konsep matematika siswa yang mengikuti pembelajaran dengan pendekatan flipped classroom lebih baik daripada pemahaman konsep matematika siswa yang mengikuti pembelajaran konvensional.

\section{Simpulan}

Berdasarkan hasil pengujian hipotesis dan pembahasan yang telah dipaparkan pada bab sebelumnya, diperoleh bahwa nilai $t_{\text {hitung }}=3,645$ sedangkan nilai $t_{\text {tabel }}=1,669$ yang artinya $t_{\text {hitung }}>t_{\text {tabel }}$ sehingga dapat disimpulkan bahwa pemahaman konsep matematika siswa yang mengikuti pembelajaran dengan pendekatan flipped classroom lebih tinggi daripada pemahaman konsep matematika siswa yang mengikuti pembelajaran konvensional. Dengan kata lain pendekatan flipped classroom berpengaruh positif terhadap pemahaman konsep matematika siswa.

\section{Daftar Pustaka}

Alifia, Nugrahaning N. (2017). “Analisis Deskriptif Soal Ujian Nasional Matematika SMA Program IPA Tahun Ajaran 2015/2016 Ditinjau dari Apsek Kognitif TIMSS”. Naskah publikasi Universitas Muhamadiyah Surakarta. Retrieved from https://eprints.ums.ac.id/ 49999/13/Naskah\%Publikasi.pdf.

Drake, Lynne dkk. (2016). "A 2020 Vision For Public Education in Ultster Country : The Flipped Classroom, An Approach to Teaching and Learning”. Retrieved from http://www.newpaltz.edu/benja mincenter/2020.html.

Jacob, Enfiel. (2013). "Looking at the Impact of the Flipped Classroom Model of Instruction on Undergraduate Multi-media Student at CSUN". Teach-Trend, 57(6), 14-18. Retrieved from https://link.springer.com/article/10.1007/s11528013-0698-1

Lokadata. (2017). Nilai Rata-Rata Ujian Nasional Matematika Tingkat SMA. Retrieved from https://lokadata.beritagar.id/chart/preview/nilai-rata-rata-ujian-nasional-matematika-tingkat-sma-1509004681.

Mahayukti, G. A, dkk. (2015). Kontribusi Kecerdasan Spasial dan Kemandirian belajar Terhadap Pemahaman Konsep Matematika Siswa SMA Negeri di Kecamatan Buleleng. Prosceedings Seminar Nasional FMIPA UNDIKSHA $V$.

Maulipaksi, Desliana. (2017). "Siswa Bisa Pilih Mata Pelajaran Jurusan di UN, Ini Alasannya". Retrieved from https://www.kemendikbud.go.id/2017/01/siswa-bisa-pilih-mata-pelaja ran-jurusan-di-un-ini-alasannya.

NCTM. 2000a. Principles and Standards for School Mathematics. USA : LCC.

NCTM.2000b. Mathematics Assessment : A Practical Handbook for Grade 6-8. USA : LCC.

Peraturan Menteri Pendidikan dan Kebudayaan No. 22 Tahun 2016 Tentang Standar Proses Pendidikan Dasar dan Menengah

Peraturan Menteri Pendidikan dan Kebudayaan No. 59 Tahun 2014 Tentang Kurikulum 2013 Sekolah Menengah Atas/Madrasah Aliyah.

Prahara, Haris. (2017). Pada 2020, Tak Ada Lagi Pelajaran Matematika di Negara Ini. Retrieved from http://edukasi.kompas.com/read/2017/09/19/13445611/pada-2020-tak-ada-lagi-pelajaran-matematika-dinegara-ini.

Pratista, I G. N. Y, dkk. (2017). Efektivitas Media Pembelajaran E-Learning Berbasis Quipper School Terhadap Pemahaman Konsep Matematika Siswa Kelas X Di SMA Laboratorium Undiksha. Jurnal Pendidikan Matematika, 8(2). Retrieved from https://ejournal.undiksha.ac.id/index.php/JJPM/article/view/13087.

Purwanti, Rahmadani D.,dkk. (2016).’Pengaruh Pembelajaran Berbantuan Geogebra Terhadap Pemahaman Konsep Matematis Ditinjau dari Gaya Kognitif”. Retrieved from http://ejournal.radenintan.ac.id/index.php/aljabar/article/view/131/121.

Samsidim, I W. Dipta, dkk. (2014). Pengaruh Model pembelajaran Generatif Berbantuan ICT terhadap Pemahaman Konsep Matematika Siswa Kelas X Mipa SMA Negeri 4 Singaraja. Jurnal Pendidikan Matematika, 2(1). 
Sun, Jerry T.Y dan Yu-Ting Wu. (2016). Analysis of Learning Achievement and Teacher-Student Interactions in Flipped and Conventional Classrooms. International Review of Research in Open and Distributed Learning, 17(1), 79-99. Retrieved from $\underline{\text { https://files.eric.ed.gov/fulltext/EJ1090880.pdf. }}$

Turan, Z. \& Goktas Y. (2016). The Flipped Classroom: Instructional Efficency and Impact of Achievement and Cognitive Load Levels. Journal of e-Learning and Knowledge Society, 12(4), 51-62. Retrieved from https://www.researchgate.net/publication/3086943

33_The_flipped_classroom_Instructional_efficiency_and_impact_on_achievement_and_cognitive_load_levels.

Uzunboylu, H. dan Damla K. (2015). Flipped Classroom: A Review of Recent Literature. World Journal on Educational Technology, 7(2), 142-147. Retrieved from https://doaj.org/article/10bbf021a8b94208b450ce0b92cf3528. 